\title{
The diagenetic formation of metal-rich layers in sapropel-containing sediments in the eastern Mediterranean
}

\author{
Peter A. Pruysers, ${ }^{1}$ Gert J. de Lange, ${ }^{1}$ Jack J. Middelburg, ${ }^{1, *}$ and David J. Hydes ${ }^{2}$ \\ ${ }^{1}$ Department of Geochemistry, Institute of Earth Sciences, University of Utrecht, P.O. Box 80.021, 3508 TA Utrecht. The Netherlands \\ ${ }^{2}$ Institute of Oceanographic Sciences Deacon Laboratory, Wormley, Godalming, Surrey GU8 5UB, UK
}

(Received February 25, 1992; accepted in revised form July 24, 1992)

\begin{abstract}
Two cores recovered from different locations in the eastern Mediterranean contain intercalations of organic-rich sapropels in organic-poor hemipelagic sediments. In both cores enrichments of $\mathrm{Mn}$ and $F e$ were found in the oxidised section of the sediment, above the sapropel $S_{1}$. The sediments followed a diagenetic cycle, which began after the sapropel formation finished (about 7000 years ago). First, during a non-steady-state diagenetic phase, metal-rich layers were formed at a downward moving oxidation front. The front decelerated at the top of the sapropel as a consequence of increasing amounts of $\mathrm{C}_{\mathrm{org}}$ and sulphides that had to be oxidised. During the second part of this non-steady-state phase, the oxidation front starts moving upwards with respect to the sapropel. Manganese is remobilised in preference to iron due to thermodynamics, reinforced by kinetics. When the upward movement of the oxidation front becomes equal to the sedimentation rate, steady-state is established with respect to the new organic-poor sedimentary circumstances. At location $31 \mathrm{GI}$, the system is at or close to steady-state. At location $9 \mathrm{Gl}$, however, this steady-state phase has never been reached. Between 1900 and 1350 years BP, the organic carbon accumulation rate probably increased suddenly, inducing a retreat of the oxidation front and the non-steady-state formation of double peaks.
\end{abstract}

\section{INTRODUCTION}

GEOCHEMICAL RESEARCH on pelagic and hemipelagic sediments has focused mainly on steady-state diagenesis (LYNN and BONATTI, 1965; HARTMANN et al., 1973; FrOELICH et al., 1979; EMERSON et al., 1980; KLINKHAMMER et al., 1982; BERGER et al., 1983). Under such post-depositional conditions metal-rich layers may form at a specific depth in the sediment with respect to the sediment surface. This depth is determined by a balance between fluxes of oxidants (e.g., $\mathrm{O}_{2}$ and $\mathrm{NO}_{3}^{-}$) and reductants (e.g., $\mathrm{Fe}^{2+}$ and $\mathrm{Mn}^{2+}$ ) diffusing to the metal-rich layer on the one hand and the sedimentation rate on the other hand. This definition of steady-state (FROELiCH et al., 1979) will be used in this paper. However, recent studies have shown that in some areas where steady-state conditions now prevail, non-steady-state conditions may have once existed. A permanent steady-state condition requires constant sedimentary conditions over a long period, which is not very likely in any sedimentary environment. The balance between fluxes and sedimentation rate is very delicate. When a parameter changes, the geochemical system is out of balance and during a non-steady-state interval it will pursue a new balance.

Non-steady-state processes can be responsible for the formation and preservation of metal-rich layers. Such processes have been described most extensively for interbedded pelagicturbiditic sediments in the Atlantic Ocean such as those found in the Madeira and Nares Abyssal Plains (COLLEY et al., 1984; WILSON et al., 1985, 1986; DE LANGE, 1986; DE LANGE and RISPENS, 1986; BUCKLEY and CRANSTON, 1988; THOMSON et al. 1989). For these sediments WILSON et al. (1985,

Publication no. 631 Netherlands Institute of Ecology, centre for Estuarine and Coatal Ecology, Yerseke, the Netherlands.
1986) developed a model that describes the formation of metal-rich layers at a progressively downward moving oxidation front. This non-steady-state process is initiated by a change in depositional conditions such as increasing bottomwater oxygen contents or decreasing organic carbon accumulation rates. Under these conditions, the downward flux of oxidants in the porewater might not be balanced by an upward flux of reductants such as $\mathrm{Fe}^{2+}$ and $\mathrm{Mn}^{2+}$. The excess is then consumed through the oxidation of labile organic carbon and reduced sulphur compounds, and the oxidation front moves downward. The extent of imbalance between the fluxes, the sedimentation rate, and the local concentrations of $C_{\text {org }}$ and reduced $S$ determines the rate of this downward movement. Therefore, the initial rapid downward movement of the oxidation front will slow exponentially with time as the increased diffusion path length lowers the oxidant flux. Downward movement will finally cease when the oxidative and reductive fluxes are again in balance, i.e., when steady-state with respect to the new depositional conditions has been reached. This mechanism also accounts for the location of sharply defined metal-rich layers at depth (WILSON et al., 1986).

Metal-rich layers are common features in suboxic sediments. Sediments in the central Pacific Ocean were found to contain metal-rich patches, which are thought to be formed by non-steady-state diagenesis (HARTMANN, 1979). In addition, metal-rich layers at or around the Pleistocene/Holocene transition have been reported for the eastem equatorial Pacific, the western equatorial Atlantic, the Gulf of Mexico, the Porcupine Abyssal Plain and the eastern Mediterranean (e.g., WALLACE et al., 1988). These widespread metal-rich layers may suggest changing environmental and depositional conditions (BERGER et al., 1983; FINNEY et al., 1988; DEAN et al., 1989). If the mechanism of formation and preservation 
of metal-rich layers is well understood and if this process can be put into a time perspective, these layers can be useful palaeo-environmental indicators.

Changing environmental conditions are thought to control the cyclic nature of eastern Mediterranean sediments (SIGL et al., 1978; CALVERT, 1983; DE LANGE and TEN HAVEN, 1983; SUTHERLAND et al., 1984; MURAT and GOT, 1987; DE LANGE et al., 1989; KLINKHAMMER and LAMBERT, 1989). The sediments in this area are dominated by alternating sequences of organic-poor hemipelagic sediments and sapropels or sapropelic layers (BUCKLEY et al., 1974; CALVERT, 1983; MURAT and GOT, 1987; DE LANGE et al., 1989). A sapropel is defined as a discrete layer more than $1 \mathrm{~cm}$ thick that contains more than $2.0 \mathrm{wt} \%$ organic carbon and occurs in a pelagic sediment sequence. A sapropelic layer is defined as containing less than $2.0 \mathrm{wt} \%$ but more than $0.5 \mathrm{wt} \%$ organic carbon. These definitions are based upon changes in sediment colour: from brown to grey at $0.5 \mathrm{wt} \%$ and from grey to black at $2.0 \mathrm{wt} \%$ (SIGL et al., 1978; KIDD et al., 1978). For practical purposes both sapropels and sapropelic layers are referred to as sapropels in this paper. The particularly strong contrasts between sedimentation periods make the eastern Mediterranean an ideal area to study the non-steady-state formation of metal-rich layers. Conditions that arise after deposition of the sapropel favour the development of a downward moving oxidation front, regardless of the causes of the environmental changes.

In this paper the formation of metal-rich layers in the eastern Mediterranean will be discussed. Porewater data will be used to demonstrate that metal-rich layers are actively forming. High resolution sediment data are applied to determine the nature and location of metal enrichments and the distribution of organic matter. Using flux calculations, the process of formation will be put into a time frame that starts with the deposition of the upper sapropel and ends at present conditions.

\section{MATERIALS AND METHODS}

The two gravity cores ( $9 \mathrm{Gl}$ and $31 \mathrm{G1}$ ) discussed in this paper were recovered during the 1987 Circum Crete Cruise with RV Tvro in the eastern Mediterranean (Fig. 1).

The shipboard routine has been described in detail elsewhere (DE LANGE, 1986). Porewater extraction was started within $12 \mathrm{~h}$ of core collection and took place at in situ temperature $\left(13^{\circ} \mathrm{C}\right)$. Samples for porewater extraction were taken after the top $\mathrm{mm}$ of sediment had been removed to prevent the inclusion of any oxidised or contaminated material. Pressure filtration under a nitrogen atmosphere $\left(\mathrm{O}_{2}\right.$ $<0.003 \%$ ) was used to extract the samples.

Nitrate was measured on board with a Technicon Traacs 800 auto analyzer using an automated method (STRICKLAND and PARSONS, 1968). The nitrate was first reduced to nitrite, which was measured. The difference between the nitrite concentration before and after

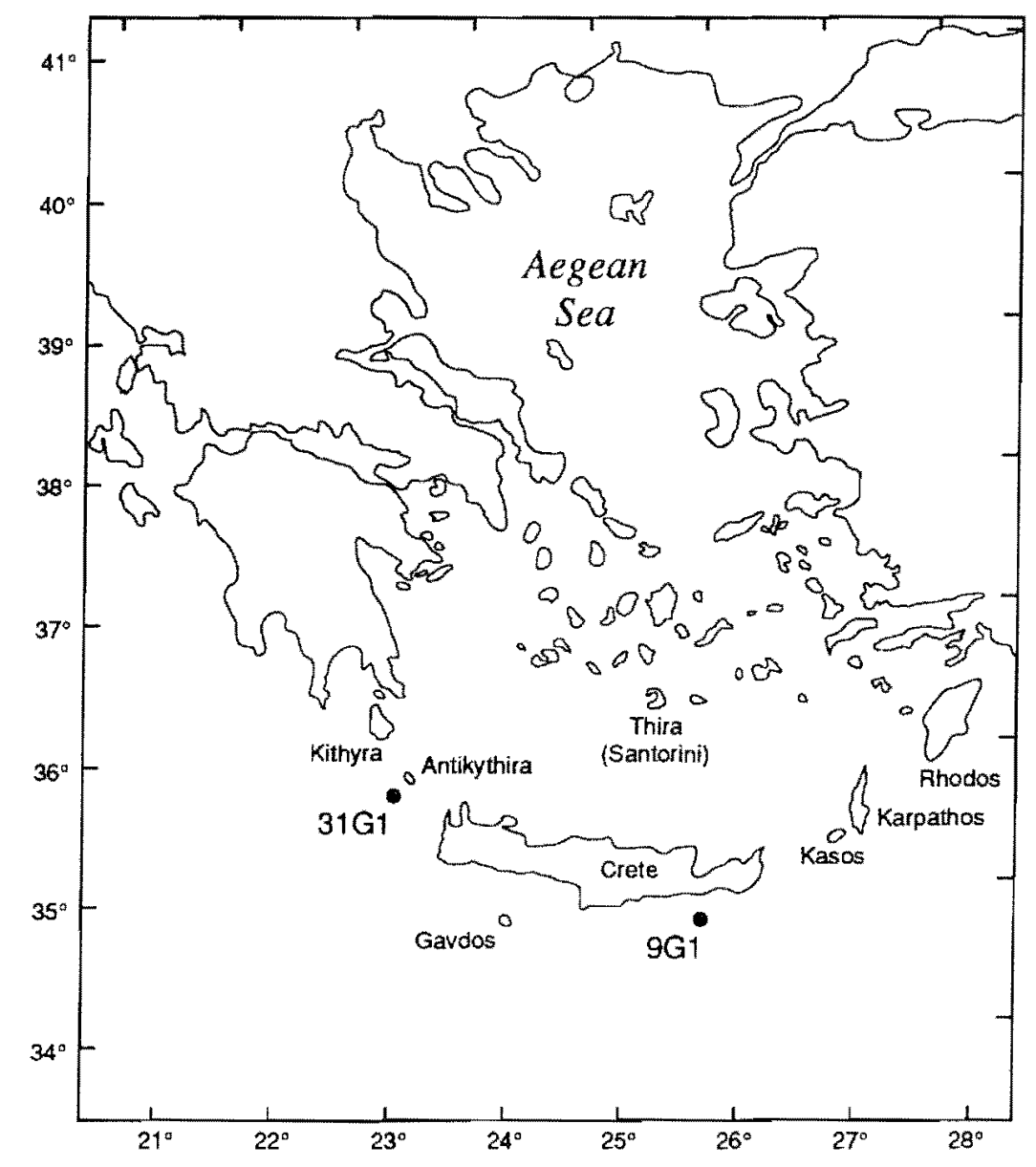

FiG. 1. Map showing the location of the cores. 
reduction gives the nitrate concentration (HYDES and HILL, 1985). Dissolved manganese and iron were measured colorimetrically on board ship, as well as by routine Inductively Coupled Plasma Emission Spectrometry (ARL 34000) at the laboratory in Utrecht. The results for dissolved $\mathrm{Mn}$ and Fe obtained by the two methods were consistent within their analytical errors. Only the ICPES data are reported because of their higher internal consistency.

Prior to analysis, sediment samples were dried at $105^{\circ} \mathrm{C}$ and finely ground in an agate mortar. Following digestion in a mixture of hydrofluoric, nitric, and perchloric acids, final solutions were made up in I $\mathrm{NHNO}_{3}$ and analyzed by ICPES for $\mathrm{Fe}, \mathrm{Mn}$, and $\mathrm{S}$. The quality of the analysis was monitored by the inclusion of some laboratory and international standards. The organic carbon content was determined in duplicate by a sulphuric acid/dichromate oxidation. A solution of potassium dichromate in concentrated sulphuric acid was added to the samples. $\mathrm{Cr}(\mathrm{V} 1)$ is reduced by the organic matter to $\mathrm{Cr}$ (111). The remaining $\mathrm{Cr}$ (VI) concentration is determined by $\mathrm{t} i$ tration with a $\left(\mathrm{NH}_{4}\right)_{2} \mathrm{Fe}\left(\mathrm{SO}_{4}\right)_{2} \cdot 6 \mathrm{H}_{2} \mathrm{O}$ solution (SIMS and $\mathrm{HABY}$, 1971). Dry combustion at $900^{\circ} \mathrm{C}$ was performed on some samples as a second method to determine $C_{\text {org }}$ concentrations. Prior to analysis, inorganic carbon was removed by adding $1 \mathrm{~N} \mathrm{HCl}$ to the samples. The samples were shaken for 24 hours and the procedure was repeated. The dry combustion method yielded systematically about $16 \%$ higher concentrations, but the trend in the $C_{\text {org }}$ profiles was not affected by the choice of method. The $\mathrm{Cr}$ (V1) method yields minimum $\mathrm{C}_{\text {org }}$ results because probably not all organic matter is reduced, while the dry combustion method yields maximum $\mathrm{C}_{\text {org }}$ results because possibly not all inorganic carbon is removed prior to analysis.

A four-step sequential extraction method was performed on some samples at room temperature (LORD, 1982; HUERTA-DIAZ and Morse, 1990). The acids used in subsequent, sequential steps are 6 $\mathrm{N} \mathrm{HCl}(1), 1: 1 \mathrm{HF}: \mathrm{H}_{2} \mathrm{O}(2), \mathrm{HNO}_{3}(3)$, and an $\mathrm{HF} / \mathrm{HClO}_{4} / \mathrm{HNO}_{3}$ mixture (4). These sequential steps yield a.o. the following mineral phases: (1) carbonates, (oxyhydr)oxides, porewater constituents, and adsorbed ions; (2) alumino-silicates; (3) pyrite, constituents of organic matter; (4) zircon, rutile, titano-magnetite, and other refractory minerals. These mineral phases are operationally defined, i.e., the reagents used are not completely selective regarding the attack of a given mineral phase. Therefore, care should be taken with the quantitative interpretation of the extraction results (NIREL and MOREL, 1990; TESsIER and CAMPBELL, 1991). The samples were analyzed by ICPES and the procedure was checked with total digestion of the same samples. One application of this method is to determine the pyrite content of the sapropels.

Pyrite and acid volatile sulphur (AVS) contents were also determined by a polarographic technique (EG\&G Princeton Applied Research, Model 384B Polarographic Analyzer). The samples used for this method had been stored for four years at $-20^{\circ} \mathrm{C}$ in sealed bags. The samples for pyrite analysis were dried at $40^{\circ} \mathrm{C}$. The pyrite-S was converted to $\mathrm{HS}^{-}$by $\mathrm{Cr}(\mathrm{II})$ reduction and subsequent $\mathrm{H}_{2} \mathrm{~S}$ trapping in $\mathrm{NaOH}$. The samples for the AVS analysis were processed without drying. The AVS was converted to $\mathrm{HS}^{-}$by acidification and subsequent $\mathrm{H}_{2} \mathrm{~S}$ trapping in $\mathrm{NaOH}$. The $\mathrm{HS}^{-}$was measured by polarography at a potential of $-0.68 \mathrm{~V}$. The results were checked by comparison with a $\mathrm{Na}_{2} \mathrm{~S}$ standard with the same matrix as the samples $\left(1.0 \mathrm{~N} \mathrm{NaOH}\right.$, previously purged with $\mathrm{N}_{2}$ ) (HENNEKE et al., 1991).

\section{RESULTS}

An interval that is relatively high in total sulphur and in organic carbon occurs in both cores (31G1 and 9G1, Fig. 2 ). The concentrations of these two constituents increase to a maximum value towards the bottom of this interval, upon which they decrease to relatively low values in the organicpoor sediments.

The nitrate porewater concentration rapidly decreases to a low concentration in both cores ( Fig. 3). If metal-rich layers are actively forming, both $\mathrm{O}_{2}$ and $\mathrm{NO}_{3}^{-}$must become zero at the oxidation front depth, i.e., at about $10 \mathrm{~cm}$ and $15 \mathrm{~cm}$
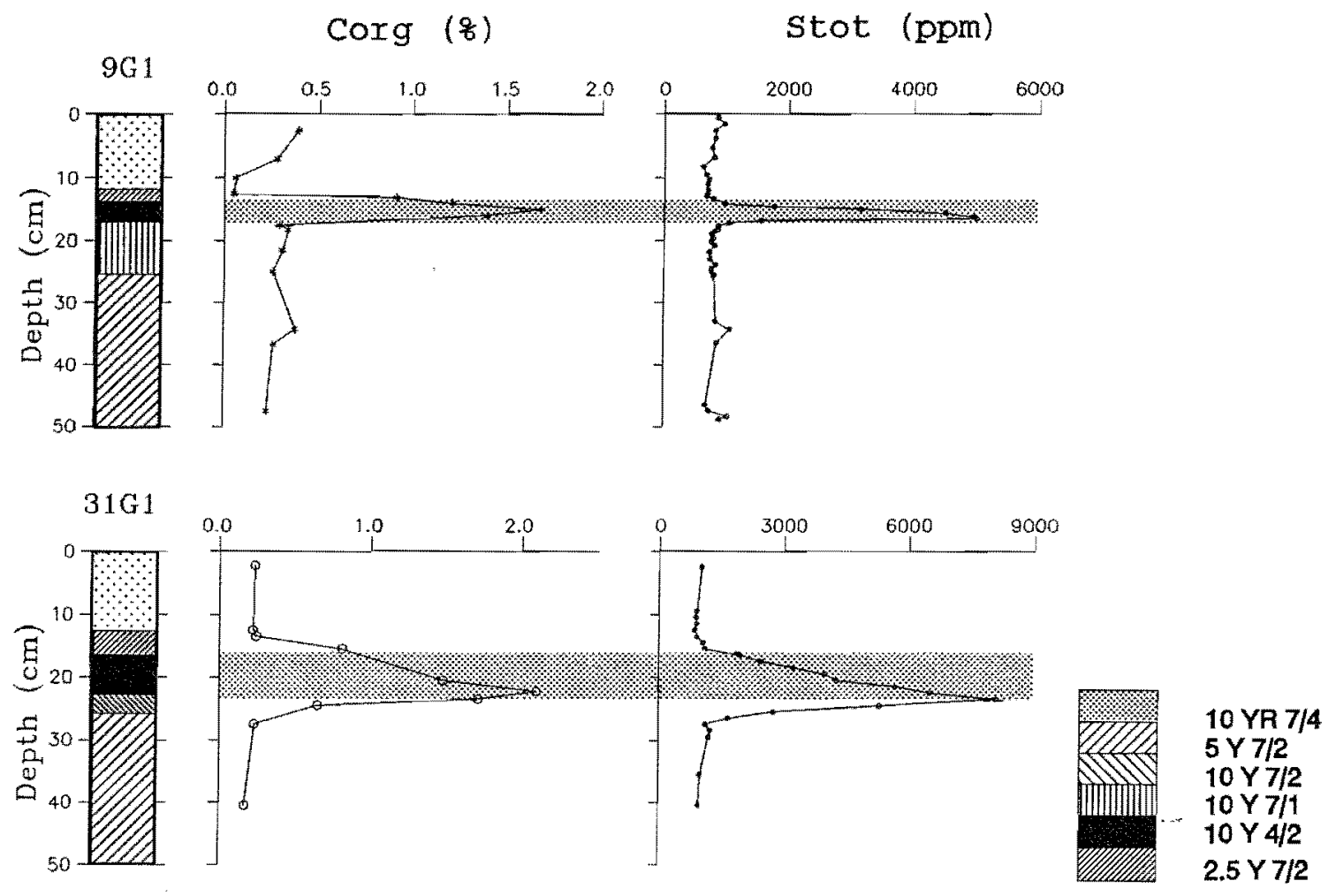

FiG. 2. Concentration vs. depth profiles of $\mathrm{C}_{\text {org }}$ and $\mathrm{S}$. Note that the shape of the $\mathrm{C}_{\text {orz }}$-plots may be influenced by a lower sample resolution than in the $S_{\mathrm{wel}}$-plots. The dotted bars represent the sapropels and the legend shows the Munsell colours. 

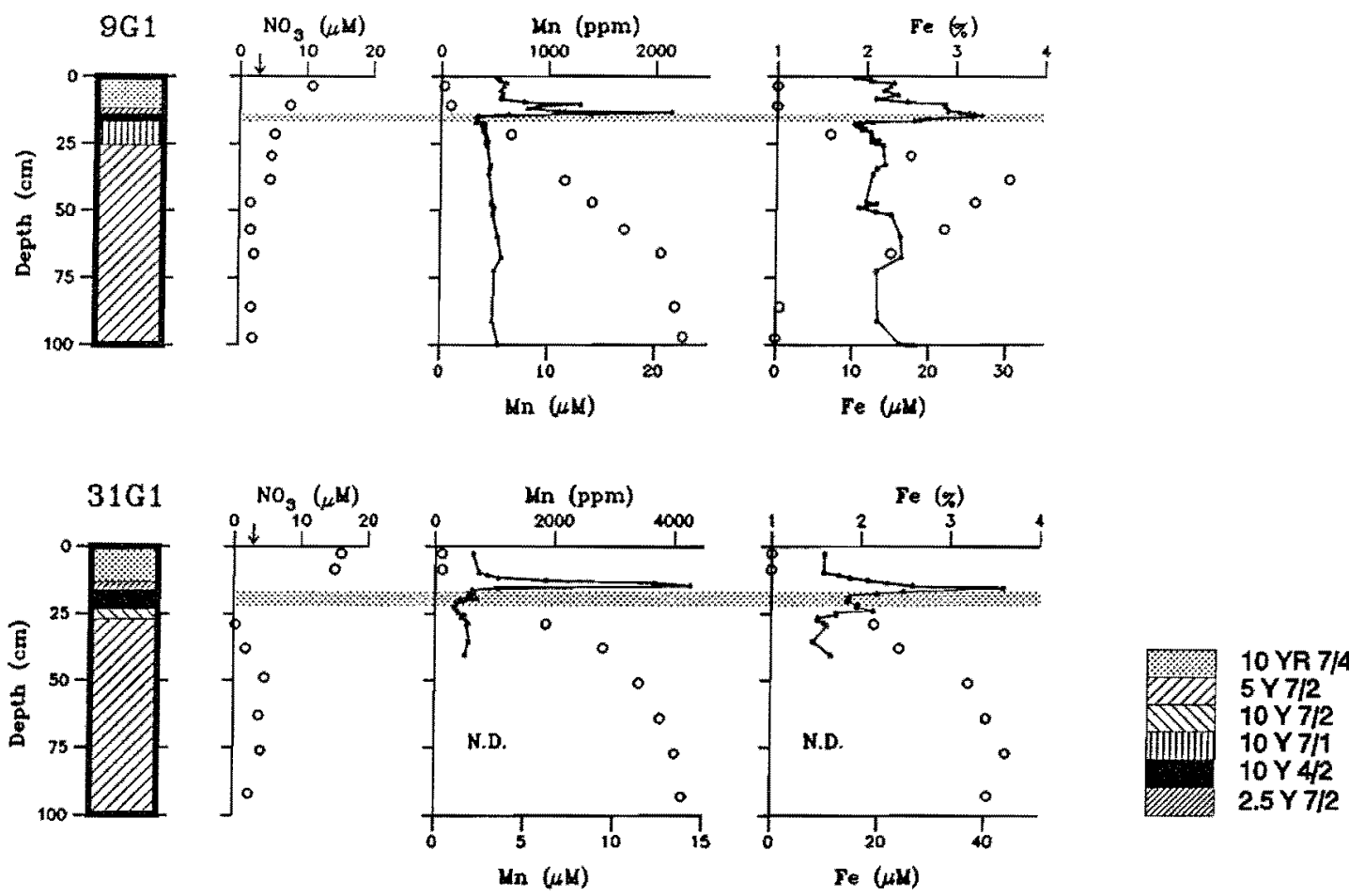

Fig. 3. Concentration vs. depth profiles of solid phase $\mathrm{Fe}$ and $\mathrm{Mn}$, and of dissolved $\mathrm{NO}_{3}^{-}, \mathrm{Mn}$, and Fe. The open dots are porewater results. The arrows in the $\mathrm{NO}_{3}^{-}$-profiles stand for the bottomwater concentrations (after HYDES et al., 1988). N.D. stands for no data.

for locations $9 \mathrm{G} 1$ and $31 \mathrm{G} 1$, respectively (Fig. 3). At depths where the concentration of nitrate becomes low, $\mathrm{Mn}$ (II) and Fe(II) are mobilised (Fig. 3). Accordingly, the porewater profiles of $\mathrm{Mn}$ and $\mathrm{Fe}$ both demonstrate low concentrations in the upper part, followed by an almost simultaneous increase with depth until a maximum concentration is reached (Fig. 3). At the upper limit of the Fe and Mn porewater profiles, the convex shapes of the profiles indicate the occurrence of sinks of these elements in a distinct interval coinciding with the solid-phase $\mathrm{Mn}$ and $\mathrm{Fe}$ peaks.

The concentration of solid phase Mn demonstrates a large enrichment at the depth of the upper inflection in the dissolved $\mathrm{Mn}^{2+}$ profile in both cores (Fig. 3 and 4). At location $9 \mathrm{Gl}$, the Mn enrichment is composed of two separate peaks. The enrichments occur in dark brown layers, which are about $3 \mathrm{~cm}$ and $5 \mathrm{~cm}$ thick for cores $31 \mathrm{Gl}$ and $9 \mathrm{Gl}$, respectively, and contain numerous fine laminations. The maximum value of the Fe enrichment lies just below the solid-phase Mn peak. At location $9 \mathrm{G1}$, the Fe peak is broadened but is not resolved into two peaks, as is the case for Mn (Fig. 4).

A large part of the reduced $S$ in the sapropels is present as pyrite $\left(\mathrm{FeS}_{2}\right.$ ) (Fig. 5). The pyrite contents determined by the extraction and the polarographic method are identical. The highest pyrite contents are found in the lower part of the $S_{1}$ sapropel in both cores. At location $31 G 1$, the total $S$ content of the sapropel is almost completely balanced by the porewater $\mathrm{SO}_{4}^{2-}$ plus the pyrite-S content. At location $9 \mathrm{G} 1$, however, a large fraction of the total $S$ at the top of the sapropel must be attributed to another $\mathrm{S}$-species (Fig. 5). $\mathrm{HCl}$ extractable iron, which is considered to be iron reactive to- wards $\mathrm{H}_{2} \mathrm{~S}$ (BERNER, 1984), is present throughout the sapropels.

\section{DISCUSSION}

\section{Organic Carbon and SuIphur}

\section{Sapropel deposition and sulphate reduction}

Extensive ${ }^{14} \mathrm{C}$ measurements have shown that sapropel $\mathrm{S}_{1}$ was deposited between 9000 and $7000 \mathrm{yr}$ BP (VERGNAUD GRAZZINI et al, 1986). Almost all ${ }^{14} \mathrm{C}$ measurements fall in this range, although there are some exceptions: SUTHERLAND et al. (1984) dated the top of the $S_{1}$ at about $6400 \mathrm{yr}$ BP, whereas RossIGNOL-STRICK et al. (1982) dated the bottom of the $S_{1}$ at $11,760 \mathrm{yr} \mathrm{BP}$. If early diagenetic reactions are ignored, then the $\mathrm{C}_{\text {org }}$-profile is a reflection of palaeo-conditions at the time of deposition of this sapropel. The primary production rate, dilution with terrigenous material, and the preservation of organic matter determine this primary signal. A close correlation exists between $\mathrm{C}_{\text {org }}$ and $\mathrm{S}$ at both locations (PRUYSERS et al., 1991). This correlation has been found in various environments (e.g., BERNER, 1984) and can be explained by the occurrence of bacterial sulphate reduction at the time of deposition of an organic carbon-rich layer, leading to the precipitation of Fe sulphides. It is the amount of metabolizable organic matter rather than the amount of reactive iron or sulphate that is the limiting factor for iron sulphide formation in this case (BERNER, 1984). This is consistent with the observed presence of reactive iron (fraction IV) in the sapropels at both locations (Fig. 5). The bulk solid phase 


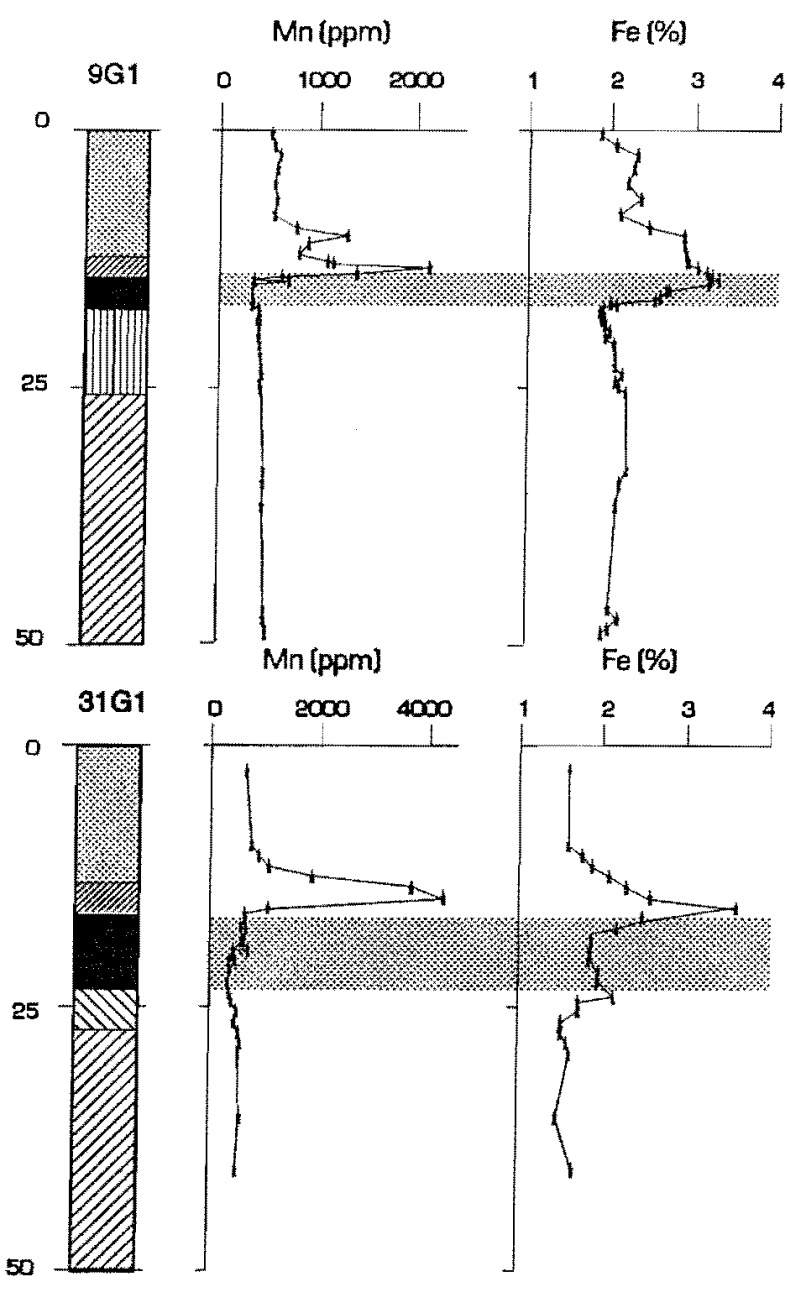

FIG. 4. Concentration vs. depth profiles of solid phase Fe and Mn on an expanded scale. Note the different scales for $\mathrm{Mn}$.

S-profile may, therefore, reflect primary effects, although the S-enrichment itself is diagenetic.

Comparison of the $\mathrm{S}$ contents obtained by total extraction with those obtained by taking the sum of the extraction steps implies that other S-species than pyrite or $\mathrm{SO}_{4}^{2-}$ are present at the top of sapropel $S_{1}$ at location $9 \mathrm{G} 1$ and to a lesser extent at location $31 \mathrm{Gl}$. Sulphate-minerals are primarily extracted in the first extraction step and organic sulphur is extracted in the first or third step, depending on the solubility of the organic sulphur compounds in $\mathrm{HCl}$. Furthermore, elemental sulphur and polysulphides (zerovalent $S$ ) are not reduced to $\mathrm{H}_{2} \mathrm{~S}$ when subjected to $\mathrm{HCl}$ or oxidising acids (e.g., JбRGENSEN et al., 1979). The only remaining possibility is acid volatile sulphur (AVS), which escapes from solution as $\mathrm{H}_{2} \mathrm{~S}$ during the first extraction step with $6 \mathrm{~N} \mathrm{HCl}$. Although polarography measurements did not reveal AVS in the sapropels, it is likely that some oxidation has occurred during storage of the samples that were used for this technique. Assuming all AVS is present as FeS, an iron speciation diagram can be made (Fig. 5).

Iron monosulphide (FeS) is generally assumed to be an intermediate product in the process of sedimentary pyrite formation (GOLDHABER and KAPLAN, 1974; J6RGENSEN,
1977; BERNER, 1984; SKYRING, 1987; HENNEKE et al., 1991). Pyrite is then formed by the reaction of FeS with zerovalent sulphur. The relatively high FeS concentration in sapropel $\mathrm{S}_{1}$ at location $9 \mathrm{Gl}$ compared to the $\mathrm{FeS}_{2}$ concentration in the same sapropel and the low FeS concentration in the $S_{1}$ at location $31 \mathrm{Gl}$ may well be related to the low availability of zerovalent sulphur. This zerovalent sulphur may form as a result of the oxidation of $\mathrm{H}_{2} \mathrm{~S}$ and $\mathrm{FeS}$ by oxidants such as $\mathrm{O}_{2}, \mathrm{NO}_{3}, \mathrm{MnO}_{2}$, and $\mathrm{FeOOH}$. The $\mathrm{S}_{1}$ at both locations contain abundant $\mathrm{Fe}$-(oxyhydr)oxides that may oxidise $\mathrm{H}_{2} \mathrm{~S}$ and/ or FeS, forming zerovalent sulphur. In this respect it seems strange that the top of sapropel $S_{1}$ at location $9 \mathrm{Gl}$ contains the most FeS. The sedimentation rate and the maximum $C_{\text {org }}$ concentration are lower at this location, which would imply a more strongly oxidising environment at the top of the sapropel than at location $31 \mathrm{G1}$. Furthermore, the mottled and reworked appearance of the $S_{1}$ at $9 \mathrm{Gl}$ may point to bioturbation during sapropel deposition (PRUYSERS et al., 1991), while no evidence for bioturbation has been found in the $S_{1}$ at $31 \mathrm{Gl}$. If the pathway for pyrite formation is correct, the $\mathrm{Fe}$-speciation results are hard to explain and further research on fresh samples is needed.

\section{Burn-down by the oxidation front}

After deposition of a sapropel, conditions become favourable for the initiation of a downward moving oxidation front; $\mathrm{C}_{\text {org }}$ and solid-phase reduced $\mathrm{S}$ are burned down and the primary signal is overprinted by this diagenetic, secondary signal. The oxidation front is active at a sharply defined depth in the sediment, At or close to this depth both the Fe and $\mathrm{Mn}$ rich layers are formed. If the oxidation front has burned into the sapropel, the $\mathrm{C}_{\text {org }}$ - and S-profiles will show sharp discontinuities at the maximum extension of the front because of the sharp depth allocation of the front. These discontinuities are reflected in the sediment colour by a sharp border between brown and green/black intervals. At both locations, the sapropels have sharp boundaries with the overlying sediment, but clear discontinuities in the $\mathrm{C}_{\text {org }}$ and solid phase $S$ profiles at these boundaries are not observed within our sampling resolution. Therefore, judging from the $S$ profiles with resolutions of more than one sample per $\mathrm{cm}$, the distance over which the sapropel-intervals are burned down is $1 \mathrm{~cm}$ at most.

When the downward moving oxidation front reaches the top of the sapropel, its migration rate decreases as it encounters increasing amounts of organic carbon and sulphides. Oxidation of organic matter and sulphides proceeds as represented by reactions $1-3$. The oxidation of organic matter is assumed to occur by $\mathrm{O}_{2}$ only, although other (secondary) oxidants such as $\mathrm{NO}_{3}$ may oxidise some $\mathrm{C}_{\text {org }}$ as well. Possible oxidants for sulphide oxidation are $\mathrm{O}_{2}, \mathrm{Mn}(\mathrm{IV})$, and $\mathrm{Fe}(\mathrm{III})$ (ALLER and RUDE, 1987; LUTHER, 1987). Oxidation by $\mathrm{Mn}$ (IV), however, is ruled out because it is probably not available in the sapropels and there is no evidence for extensive mixing by bioturbation of the sapropel and the overlying sediment. Fe(III), on the other hand, is still available in the sapropels (Fig. 5) because Fe(III) did not limit sulphide formation during sapropel deposition. Additionally, the oxidation of sulphides with $\mathrm{Fe}(\mathrm{III})$ is an order of magnitude faster than with $\mathrm{O}_{2}$ (e.g., LUTHER, 1987; LUTHER et al., 1991). 
A

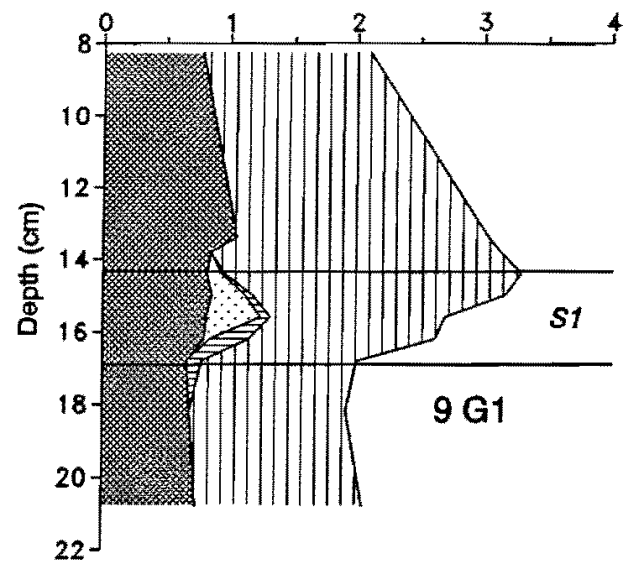

$F \oplus(\%)$

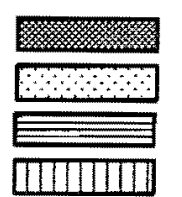

III Pyrite

I Iron silfcates and crystalline iron oxides

II Monosulfides

IV Iron(hydr)oxides and carbonate bound iron

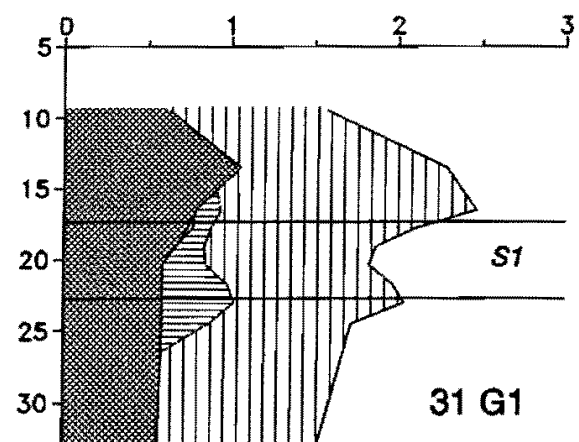

B

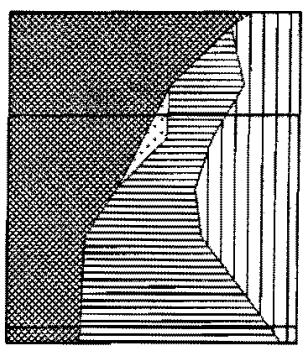

FrG. 5. (a) Fe speciation in sapropel $S_{1}$ at both locations. $I=F e$ in Fe silicates and crystalline Fe oxides (1:1 HF); $I I=\mathrm{Fe}$ in Fe monosulphides; III = Fe in pyrite $\left(\mathrm{HNO}_{3}\right) ; \mathrm{IV}=\mathrm{Fe}$ in $\mathrm{Fe}$ (oxyhydr) oxides and carbonates $(6 \mathrm{~N} \mathrm{HCl})$. (b) Blow-up of the $S_{1}$ at location $31 \mathrm{Gl}$, showing a tiny FeS field at the top of the sapropel.

Therefore, the oxidation of sulphides in sapropels that are not bioturbated after deposition primarily occurs by $\mathrm{Fe}(\mathrm{III})$ :

$$
\begin{aligned}
\mathrm{CH}_{2} \mathrm{O}+\mathrm{O}_{2} & \rightarrow \mathrm{CO}_{2}+\mathrm{H}_{2} \mathrm{O} \\
8 \mathrm{H}_{2} \mathrm{O}+\mathrm{FeS}_{2}+14 \mathrm{Fe}(\mathrm{III}) & \rightarrow 15 \mathrm{Fe}^{2+}+16 \mathrm{H}^{+}+2 \mathrm{SO}_{4}^{2-} \\
4 \mathrm{H}_{2} \mathrm{O}+\mathrm{FeS}+8 \mathrm{Fe}(\mathrm{III}) & \rightarrow 9 \mathrm{Fe}^{2+}+8 \mathrm{H}^{+}+\mathrm{SO}_{4}^{2-}
\end{aligned}
$$

The oxidation of sulphides increases the upward flux of $\mathrm{Fe}^{2+}$. This extra $\mathrm{Fe}$ (II) is readily oxidised at the front:

$$
6 \mathrm{H}_{2} \mathrm{O}+4 \mathrm{Fe}^{2+}+\mathrm{O}_{2} \rightarrow 4 \mathrm{FeOOH}+8 \mathrm{H}^{+} \text {. }
$$

Reaction 4 results in a further deceleration of the front. The influence of sulphide oxidation on this deceleration is an aspect that has not been considered in previous studies. The relative importance of this process in periodically sulphatereducing sediments such as in the eastern Mediterranean is illustrated by the following calculation. The amount of electrons that are liberated during oxidation per mole of $\mathrm{C}_{\text {org }}$ or sulphide controls the deceleration of the reaction front. From reactions 1 to 4 , it follows that 15 electrons are liberated per mole of $\mathrm{FeS}_{2}, 9$ electrons per mole of $\mathrm{FeS}$, and 4 electrons per mole of $\mathrm{C}$ oxidised. The total reduced-S/ $\mathrm{C}_{\text {org }}$ molar ratio in sapropels is about 0.405 (PRUYSERS et al., 1991). This ratio is slightly lower $(0.35)$ when the $C_{\text {org }}$ results from the dry combustion method are used. Therefore, if one mole of $C$ is oxidised in the sapropels $\left(4 \mathrm{e}^{-}\right)$then $0.35-0.41$ moles FeS $\left(3.2-3.7 \mathrm{e}^{-}\right)$or $0.18-0.20$ moles $\mathrm{FeS}_{2}\left(2.7-3.0 \mathrm{e}^{-}\right)$are oxidised. Accordingly, it seems that the presence of sulphides in sapropels almost doubles the resistance to burndown of the sapropel compared to the situation when $\mathrm{C}_{\text {org }}$ is the only reductant.

\section{Formation and Fate of Metal-Rich Layers}

Assuming that the upward $\mathrm{Fe}^{2+}$ and $\mathrm{Mn}^{2+}$ fluxes always stayed at their present magnitude, a time estimate can be made for the beginning of the formation of metal-rich layers. The idea behind such an estimate is that while the front moves downward relative to the sapropel, all previously precipitated $\mathrm{Fe}$ and $\mathrm{Mn}$ are preserved. This involves an estimate of the amount of $\mathrm{Fe}$ and $\mathrm{Mn}$ precipitated and an estimate of the fluxes based on Fick's first law:

$$
\Delta t=\frac{P A}{D\left(\frac{\delta c}{\delta x}\right)} .
$$

In this formula $\Delta t$ represents an estimate of the time it takes to build up the Fe or Mn enrichments observed at present. $P A$ is the peak area, i.e., the area of the enrichments in a concentration vs. depth diagram (Fig. 4). The units of $P A$ (initially $\mathrm{ppm} * \mathrm{~cm}$ for $\mathrm{Mn}$ and percent $* \mathrm{~cm}$ for $\mathrm{Fe}$ ) are recalculated to moles $* \mathrm{~cm}^{-2}$, assuming an average dry sediment density of $2.2 \mathrm{~g} * \mathrm{~cm}^{-3} . D$ represents the diffusion coefficient and $(\delta c / \delta x)$ the concentration gradient of $\mathrm{Fe}^{2+}$ or $\mathrm{Mn}^{2+}$. This concentration gradient was estimated from porewater profiles by taking the tangent at the point where the solidphase enrichments are at maximum and $\mathrm{Mn}^{2+}$ and $\mathrm{Fe}^{2+}$ concentrations approach zero (Fig. 3 ). At both locations $\Delta t$ values were determined for the $\mathrm{Fe}$ and $\mathrm{Mn}$ enrichments with an uncertainty of about $15 \%$ (Table 1 ). At location $31 \mathrm{G} 1$, at the present level of fluxes it took 6800-9500 years to produce the metal enrichments. This time estimate is close to the interval in which the sapropel was deposited ( $9000-7000 \mathrm{yrs}$ ). As sulphate reduction must have occurred during sapropel 
Table 1. Time estimates for the enrichments of Fe and $M n$ at the front. $D_{M n}=88.4 \mathrm{~cm}^{2}, \mathrm{yr}^{-1}, D_{F \varepsilon}$

$=91.5 \mathrm{~cm}^{2} \cdot \mathrm{yr}^{-1}$ (from $\mathrm{L}$ and GREGORY (1974), corrected for temperature and turtuosity).

Concentration gradients are estimated from pore-water profiles by taking the tangent at the point

where the enrichments are at a maximum and $\mathrm{Mn}^{2+}$ or $\mathrm{Fe}^{2+}$ are zero (Fig.3). PA (i.e. the enrichment

of solid phase Fe or Mn) is calculated from the area of the enrichment in a concentration vs. depth

diagram (Fig. 4). $\Delta t$ is an estimate of the time it takes to build up the enrichment observed at

present.

\begin{tabular}{lllll}
\hline LOCATION & ELEMENT & $\begin{array}{l}\text { FLUX } \\
\left(\mathrm{mol} . \mathrm{cm}^{-2}, \mathrm{yr}^{-1}\right)\end{array}$ & $\begin{array}{l}\text { PA } \\
\left(\mathrm{mol} . \mathrm{cm}^{-2}\right)\end{array}$ & $\begin{array}{l}\Delta \mathrm{t} \\
(\mathrm{yr})\end{array}$ \\
\hline $316 t$ & Mn & $3.74 * 10^{-8}$ & $2.99^{*} 10^{-4}$ & 8000 \\
& Fe & $1.07 * 10^{-7}$ & $8.85 * 10^{-4}$ & 8300 \\
\hline 961 & Mn (2 peaks) & $2.91 * 10^{-8}$ & $1.51 * 10^{-4}$ & 5200 \\
& Mn (upp.peak) & & $4.78 * 10^{-6}$ & 1650 \\
& Fe (2 peaks) & $1.26 * 10^{-7}$ & $7.85 * 10^{-4}$ & 6200 \\
& Fe (upp.peak) & & $2.01 * 10^{-4}$ & 1590 \\
\hline
\end{tabular}

deposition, the Mn and Fe enrichments began to develop not long after sapropel deposition at this location.

Double-peak features of $\mathrm{Fe}$ and $\mathrm{Mn}$ at location $9 \mathrm{G1} \mathrm{com}$ plicate the time estimate. This is inherent to the origin of these features. When the amount of Fe or Mn present in both peaks is considered, $\Delta t$ lies between 4500 and 7000 years (Table 1). One must remember, however, that the time estimate has been determined assuming that all precipitated Fe and $\mathrm{Mn}$ are preserved. This is no longer true at location 9G1 because the oxidation front has moved upwards. Some $\mathrm{Fe}$ and $\mathrm{Mn}$ precipitated in the upper peaks probably derives from dissolution of the lower peaks. This process leads to an underestimate of the oxidation front initiation time. However, from the porewater profiles it follows that dissolution of the lower peaks is subordinate to dissolution of solid phase $\mathrm{Fe}$ and $\mathrm{Mn}$ below these peaks (Fig. 3). The $\Delta t$ for the upper peak (1900-1350 yrs) may give the time when the separation occurred.

Based on constant reductive fluxes and a constant sediment accumulation rate, it is possible to reconstruct the time evolution of the Fe and $\mathrm{Mn}$ enrichments. The results for a few time slices are presented schematically in Fig. 6 . The oxidation front starts moving downward not long after sapropel deposition ceased (Fig. 6,t=0). However, this downward movement does not start exactly at $t=0$ because some time elapses before the downward oxygen flux reaches its present level. This time lapse may be explained by: (1) sulphate reduction in the sapropel will not stop immediately after sapropel deposition. Therefore, some $\mathrm{H}_{2} \mathrm{~S}$ may diffuse upwards into the organic-poor sediments and react with $\mathrm{O}_{2}$, thereby reducing the downward diffusion of oxygen; (2) the benthic community, which is responsible for bioturbation and thus for transporting $\mathrm{O}_{2}$ from the bottom water into the sediment, is small or completely absent during sapropel deposition and it will subsequently take some time to build up to its present size; ( 3 ) if anoxic bottom waters were present during sapropel deposition, it will take some time after sapropel deposition before $\mathrm{O}_{2}$ concentrations in the bottom water will reach their present level. Therefore, after a relatively short transitional stage, the oxidation front starts moving downward (Fig. 6, $t$ $\cong 700$, by assumption ). During this non-steady-state downward movement of the oxidation front, the geochemical system adjusts to the relatively organic-poor sedimentary input. Solid phase $\mathrm{Fe}$ and $\mathrm{Mn}$ are enriched in a narrow depth interval. As the diffusion distance of the oxidants increases, the penetration of the front slows exponentially with time (WILSON et al., 1986), until a maximum depth is reached (Fig. $6, t=6000$ ). In the case of sulphide and organic carbon-rich sapropels, this maximum depth is likely to represent the present top of the sapropel. At location $9 \mathrm{Gl}$ we assumed that the top $5 \mathrm{~mm}$ of the sapropel was burned down by the oxidation front between $t=5000$ and $t=6000$ years (Fig. 6 , hatched area). If we take the upper boundary of the sapropels as the deepest extension of the oxidation front, a maximum depth of $15.5 \mathrm{~cm}$ and $13.6 \mathrm{~cm}$ is derived for locations $31 \mathrm{G} 1$ and $9 \mathrm{G} 1$, respectively.

After $t=6000$ years the oxidation front behaves differently at both locations. At location $31 \mathrm{G} 1$, the oxidation front moves upwards with respect to the sapropel but it still moves downwards with respect to the sediment surface. At present the maximum $\mathrm{Mn}$ concentration is found at a depth of $14.5 \mathrm{~cm}$ and the maximum Fe concentration at $15.5 \mathrm{~cm}$. Therefore, manganese has been mobilised in preference to iron over a distance of $1 \mathrm{~cm}$. This preferential mobilisation is due to thermodynamics and kinetics (LYNN and BONATTI, 1965; FroeliCH et al., 1979; STUMM and MORGAN, 1981; BURDIGE and GiesKES, 1983; DE LANGE, 1986; THOMSON et al., 1989). The sharpness of the redox-transition from oxic to suboxic decreases with time as the diffusive path-length of oxygen becomes longer. Accordingly, the remobilisation of man- 


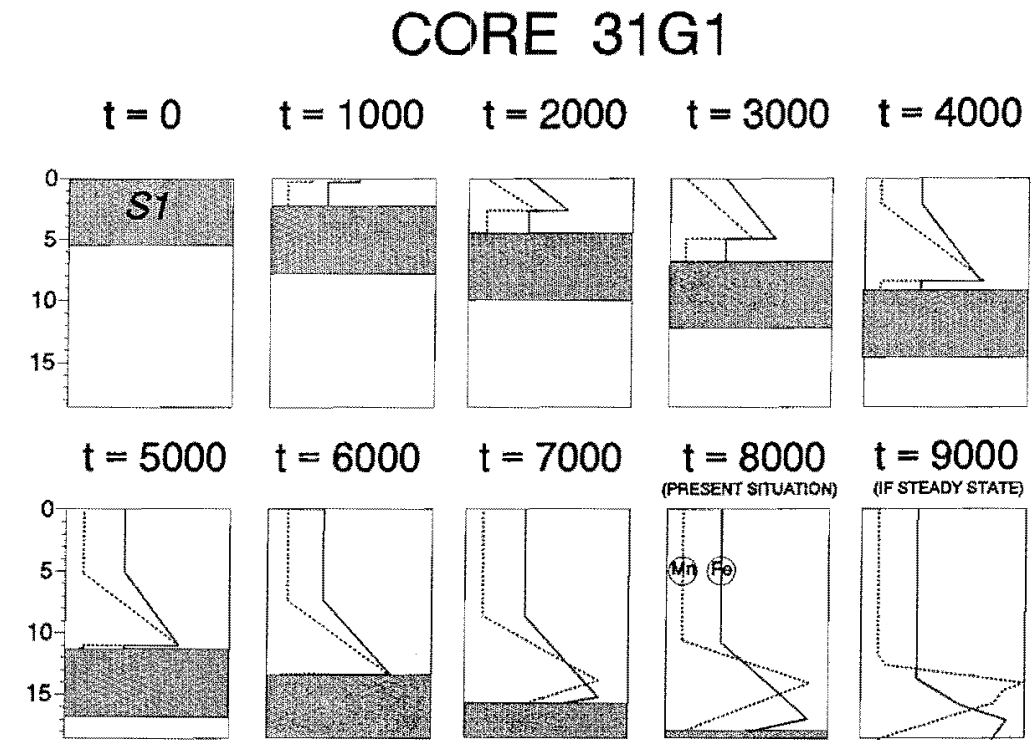

\section{CORE 9 G1}
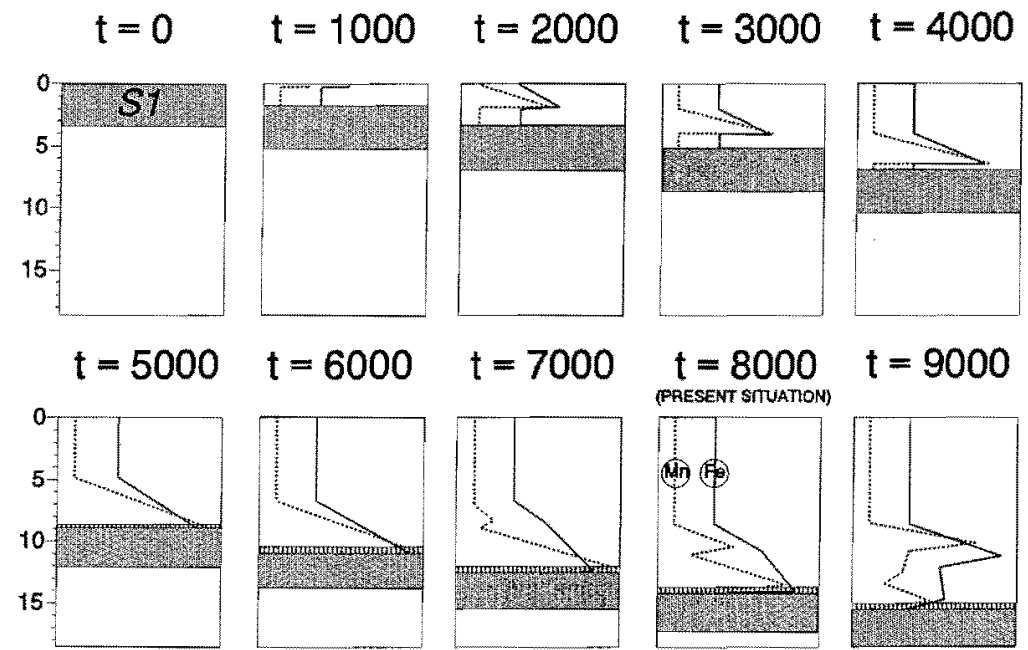

FIG. 6. Schematic representation of the development of the Fe and Mn enrichments from the end of sapropel deposition until present plus 1000 years, using timesteps of 1000 years. The end of sapropel deposition is represented by $t=0$ and present conditions by $t=8000$. The Fe profile is represented by a solid line, while the $\mathrm{Mn}$ profile is represented by a broken line. The vertically hatched area $(9 G 1, t=5000-9000)$ represents a part of the sapropel that has been oxidised completely. The dotted area represents the sapropel.

ganese in preference to iron due to thermodynamics will become larger with time. When the front moves upwards relative to the sapropel $(t>6000)$, the lower parts of the enrichments dissolve slowly. Furthermore, Mn oxides are reduced faster than Fe oxyhydroxides (STUMM and MORGAN, 1981). This kinetic effect, which reinforces the thermodynamic effect, becomes more apparent between $t=6000$ and $t=8000$ years than before $t=6000$ because of dissolution of the lower parts of the enrichments during this interval (Fig. 6). At present conditions $(t=8000)$, the system is at or close to steadystate. The oxidation front will remain at a constant distance from the sediment surface and the Fe and $\mathrm{Mn}$ enrichments move upwards in pace with the sedimentation rate (Fig. 6, $t$ $=9000)$.

At location $9 \mathrm{G} 1$, the oxidation front makes a sudden shift upwards between 1900 and 1350 years ago, probably by an increased $C_{\text {org }}$ accumulation rate. The attribution of double peaks to varying bioturbation rates by BERGER et al. (1983) does not apply to location $9 \mathrm{G} 1$ because this process would have destroyed the sharp appearance of the double Mn peaks. Contrary to the situation just after sapropel deposition when oxidative fluxes were dominant, the front moves upwards under conditions of increased $\mathrm{C}_{\text {org }}$ accumulation because reductive fluxes dominate. From this time onward, $\mathrm{Mn}$ and 
Fe are precipitated at the new position of the front (Fig. $6, t$ $=7000-9000$ ). The lower peaks will remain at the same depth relative to the sapropel and dissolve slowly. The active upper $\mathrm{Mn}$ peak lies at a depth of $10.3 \mathrm{~cm}$ and the upper peak of $\mathrm{Fe}$ at $12.8 \mathrm{~cm}$. Accordingly, $\mathrm{Mn}$ has been remobilised in preference to $\mathrm{Fe}$ over a distance of $2.5 \mathrm{~cm}$ after the upward shift of the oxidation front. The results from $9 G$ l show how sensitive the diagenetic system can be to small disturbances. If the disturbance is large enough, for instance when a new sapropel is deposited, the $\mathrm{Mn}$ and $\mathrm{Fe}$ enrichments may become buried in an anoxic environment. The (oxyhydr)oxides in the enriched horizons will slowly dissolve until they have disappeared completely (DEAN et al., 1989; VAN Os et al., 1991; PRUYSERS et al., 1991). Above the new sapropel a new diagenetic burn-down cycle may begin. The relict enrichments are often still visible in the sediment above old sapropels. For example, $\mathrm{Fe}$ and $\mathrm{Mn}$ enrichments have been found above sapropel $\mathrm{S}_{4}$ at location $9 \mathrm{G} 1$ but not above older sapropels (PRUYSERS et al., 1991). Where Mn and Fe enrichments are still detectable but where the sapropel has been burned down completely, the relict Fe and Mn enrichments can be useful geochemical palaeo-stratigraphic indicators for a vanished sapropel.

\section{CONCLUSIONS}

Early diagenesis in sapropel-containing marine sediments in the eastern Mediterranean leads to the formation of metalrich layers in a way similar to that described for other marine environments.

The diagenetic formation of the $\mathrm{Fe}$ and $\mathrm{Mn}$ enrichments began not long after sapropel deposition. After the sapropel was deposited (about 7000-8000 yrs BP) a progressive oxidation front mechanism became active, forming the diagenetic $\mathrm{Mn}$ and Fe enrichments. The downward moving front decelerated at the top of the sapropel mainly because of the increasing amounts of organic matter and reduced sulphides that had to be oxidised. During the second part of this nonsteady-state phase, the oxidation front started moving upwards with respect to the sapropel. Manganese was remobilised in preference of iron due to thermodynamics, reinforced by kinetics. Steady-state conditions are reached when the upward movement of the front becomes equal to the sedimentation rate. At present the system at location $31 \mathrm{Gl}$ is at or close to steady-state. The oxidation front will remain at a constant distance from the sediment surface, and manganese will be mobilised in preference to iron. At location $9 \mathrm{G} 1$, however, this steady-state phase has never been reached. 1900-1350 years ago the organic carbon accumulation rate probably increased suddenly, giving rise to a retreating oxidation front and the formation of double peaks.

Acknowledgments-We are grateful to the Netherlands Council of Ocean Research (NCZ) for giving financial support. Chief scientist W. J. van der Linden, $\mathrm{NIOZ} / \mathrm{NCZ}$ technicians, Captain Block and crew of the RV Tyro are thanked for their kind cooperation. We are also grateful to A. van Dijk, G. Nobbe, and A. F. Peters for analytical assistance. B. J. H. van Os, E. Henneke, C. H. van der Weijden, and three anonymous reviewers are thanked for critically reading the manuscript and providing constructive remarks. The authors greatly appreciate the linguistic advice given by Miss McNab.

Editorial handling: P. N. Froelich

\section{REFERENCES}

ALLER R. C. and RUDE P. D. (1987) Complete oxidation of solid phase sulfides by manganese and bacteria in anoxic marine sediments. Geochim Cosmochim. Acta 52,751-765.

BERGER W. H., FINKEL R. C., KILLINGLEY J. S., and MARCHIG V. (1983) Glacial-Holocene transition in deep-sea sediments: Manganese-spike in the east-equatorial Pacific. Nature 303, 231-233.

BERNER R. A. (1984) Sedimentary pyrite formation: An update. Geochin. Cosmochim. Acta 48, 605-615.

BUCKLEY D. E. and CRANSTON R. E. (1988) Early diagenesis in deep sea turbidites: The imprint of paleo-oxidation zones. Geochim. Cosmochim. Acta 52, 2925-2939.

BUCKLEY H. A., EASTON A. J., and JOHNSON L. R. (1974) Iron and manganese encrustations in Recent sediments. Nature $249,436-$ 437.

BURDIGE D. J. and Gieskes J. M. (1983) A porewater/solid phase diagenetic model for manganese in marine sediments. Amer. $J$. Sci. 283, 29-47.

CALverT S. E. (1983) Geochemistry of Pleistocene sapropels and associated sediments from the Eastern Mediterranean. Ocean. Acta 6, 255-267.

COLleY S., THOMSON J., WILSON T. R. S, and HIGGS N. C. (1984) Post-depositional migration of elements during diagenesis in brown clay and turbidite sequences in the North East Atlantic. Geochim. Cosmochim. Acta 48, 1223-1235.

DeAN W. E., Gardner J. V., and HeMPhill-Haley E. (1989) Changes in redox conditions in deep-sea sediments of the subarctic north Pacific Ocean: Possible evidence for the presence of north Pacific deep water. Paleoceanography 4, 639-653.

DE LANGE G. J. (1986) Early diagenetic reactions in interbedded pelagic and turbiditic sediments in the Nares Abyssal Plain (western North Atlantic): Consequences for the composition of sediment and interstitial water. Geochim. Cosmochim. Acta 50, 2543-2561.

DE LANGE G. J. and RISPENS F, B. (1986) Indications of a diagenetically induced precipitate of an $\mathrm{Fe}$-Sí, mineral in sediment from the Nares Abyssal Plain, western North Atlantic. Mar. Geol. 73, $85-97$.

DE LANGE G. J. and TEN HAveN H. L. (1983) Recent sapropel formation in the eastern Mediterranean. Nature 305, 797-798.

De LANGE G. J., Middelburg J. J., and PruYsers P. A. (1989) Discussion: Middle and Late Quaternary depositional sequences and cycles in the eastern Mediterranean. Sedimentology 36, 151 158.

EMERSON S, JAHNKE R, BENDER M., Froelich P., KLINKHAMMER G., BowsER C., and SETLOCK G. (1980) Early diagenesis in sediments from the Eastern Equatorial Pacific, I. Pore water nutrient and carbonate results. Earth Planet. Scl. Let. 49, 57-80.

FINNEY B.P., LYLE M, W, and HEATH G. R. (1988) Sedimentation at MANOP site $H$ (eastern equatorial Pacific) over the past 400,000 years: Climatically induced redox variations and their effects on transition metal cycling. Paleoceanography 3, 169-189.

Froelich P. N., KLINKHAMMER G. P., BENDER M. L., LUEDTKe N. A., Heath G. R., Cullen D., Dauphin P., HaMmond D., HARTMAN B., and MAYNARD V. (1979) Early oxidation of organic matter in pelagic sediments of the Eastern Equatorial Atlantic: Suboxic diagenesis. Geochim. Cosmochim. Acta 43, 1075-1090.

GOLDHABER M. B. and KAPLAN I. R. (1974) The sulfur cycle. In The Sea (ed. E. D. GoldBerG), Vol. 5, pp. 569-655. J. Wiley.

HARTMANN M. (1979) Evidence for early diagenetic mobilisation of trace elements from discolorations of pelagic sediments. Chem. Geology 26, 277-293.

HartManN M., MUller P., Suess E., and VAN DER WEIJden C. H. (1973) Oxidation of organic matter in recent marine sediments. Meteor. Forsch-Ergebnisse 12, 77-86.

HENNEKE E., LUTHER G. W. III, and DE LANGE G. J. (1991) Determination of inorganic sulphur speciation with polarographic techniques: Some preliminary results for recent hypersaline anoxic sediments. Mar. Geol. 100, 115-123.

HUERTA-DIAZ M. A. and MORSE J.W. (1990) A quantitative method for determination of trace metal concentrations in sedimentary pyrite. Mar. Chem. 29, 119-144.

HYDES D. J and HUL N.C. (1985) Determination of nitrate in 
seawater. Nitrate to nitrite reduction with copper-cadmium alloy. Estuarine Coastal Shelf Sci. 21, 127-130.

Hydes D. J., DE LANGe G. J., and DE BAAR H. J. W. (1988) Dissolved aluminium in the Mediterranean. Geochim. Cosmochim. Acta 52, 2107-2114.

JøRGENSEN B. B. (1977) The suiphur cycle of a coastal marine sediment (Limf jorden, Denmark). Limnol Oceanogr. 22(5), 814832.

JøRGENSEN B. B., KUENEN J. G., and COHEN Y. (1979) Microbial transformation of sulfur compounds in a stratified lake (Solar Lake, Sinai). Limnol. Oceanogr. 24, 799-822.

KIDD R. B., CrTA M. B., and RYAN W. B. F. (1978) Stratigraphy of Eastern Mediterranean sapropel sequences recovered during Leg $42 \mathrm{~A}$ and their paleoenvironmental significance. Init. Rep. DeepSea Drill. Proj. 42, 421-443.

KLINKHAMMER G. and LAMBeRT C. E. (1989) Preservation of organic matter during salinity excursions. Nattre 339, 271-274.

KuINKHAMmer G., HEGgie D. T, and GRAHAM D. W. (1982) Metal diagenesis in oxic marine sediments. Earth Planet. Sci. Lett. 61, $211-219$.

LI Y.-H. and GREGORY S. (1974) Diffusion of ions in sea water and in deep-sea sediments. Geochim. Cosmochim. Acta 38, 703-714.

LORD C. J. III (1982) A selective and precise method for pyrite determination in sedimentary materials. J. Sediment. Petrol. 52,664666.

LUTHER G. W. III (1987) Pyrite oxidation and reduction: Molecular orbital theory considerations. Geochim. Cosmochim. Acta 51, 3193-3199.

Luther G. W. III, Ferdelman T. G., KostKa J. E., TSAMakis E. J., and CHURCH T. M. (1991) Temporal and spatial variability of reduced sulfur species $\left(\mathrm{FeS}_{2}, \mathrm{~S}_{2} \mathrm{O}_{3}^{2-}\right)$ and porewater parameters in salt marsh sediments. Biogeochem. 14, 57-88.

LYNN D. C. and BONATTI E. (1965) Mobility of manganese in diagenesis of deep-sea sediments. Mar. Geol. 3, 457-474.

MURAT A. and Gor H. (1987) Middle and Late Quaternary depositional sequences and cycles in the Eastern Mediterranean. Sedimentology 34, 885-899.

NiREL P. M. V. and MOREL F. M. M. (1990) Pitfalls of sequential extractions. Water Res. 24, 1055-1056.

Pruysers P. A., De Lange G. J., and Middleburg J. J. (1991) Geochemistry of eastern Mediterranean sediments: Primary sediment composition and diagenetic alterations. Mar. Geol. 100, 137154.
ROSSIGNOL-STRICK M. NESTEROFF W. OLIVE P., and VergNaUd GRAzZINI C. (1982) After the deluge: Mediterranean stagnation and sapropel formation. Nature 295, 105-110.

SHAW H. F. and EVANS C. (1984) The nature, distribution and origin of a sapropelic layer in sediments of the Cilicia Basin, northeastern Mediterrancan. Mar. Geol. 61, 1-12.

Sigl $W_{*}$ Chamley H., Fabricius $F_{\text {. }}$ Giroud d'Argoud $G$, and MUELlER J. (1978) Sedimentology and environmental conditions of sapropels. Init. Rep. Deep-Sea Drill. Proj. 42, 445-465.

SIMS J. R, and HABY V. A. (1971) Simplified colorimetric determination of soil organic matter. Soll Sci. 112, 137-141.

SKYRING G. W. (1987) Sulfate reduction in coastal ecosystems. Geomicrob. J. 5, 295-374.

STRICKLAND J. D. H. and PARSONS T. R. (1968) A practical hand. book of seawater analysis. Fish. Res. B. Canada Bull. 164.

STUMm W. and MORGaN J. J. (1981) Aquatic chemistry. John Wiley and Sons.

SUTHERLAND H. E., CALVERT S. E., and MORRIS R. J. (1984) Geochemical studies of the recent sapropel and associated sediment from the Hellenic outer ridge, Eastern Mediterranean Sea: 1: Mineralogy and chemical composition. Mar. Geol, 56, 79-92.

Tessier A. and CAMpbell P. G. C. (1991) Comment on "Pitfalls of sequential extractions" by P. M. V. NIREL and F. M. M. MOREL in Water Res. 24, 1055-1056 (1990), Water Res. 25, 115-117.

THomson J., Higos N. C., and CoLley S. (1989) A geochemical investigation of reduction haloes developed under turbidites in brown clay. Mar. Geol. 89, 315-330.

VAN OS B. J. H. MIDDElBuRG J. J., and DE LANGE G. J. (1991) Possible diagenetic mobilisation of barium in sapropelic sediment from the eastern Mediterranean. Mar. Geol. 100, 125-136.

VERGNAUD GRAZZINI C., DEVAUX M., and ZNAIDI J. (1986) Stable isotope "anomalies" in Mediterranean Pleistocene records. Mar. Micropal. 10, 35-69.

Wallace H. E., Thomson J., Wilson T. R. S., Weaver P. P. E. HIGGS N. C., and HYoEs D. J. (1988) Active diagenetic formation of metal-rich layers in NE Atlantic sediments. Geochim. Cosmochim. Acta 52, 1557-1569.

WILSON T. R. S., THOMSON J., COLley S. HYDES D. J., HIGGS N. C., and SøRENSEN J. (1985) Early organic diagenesis: The significance of progressive subsurface oxidation fronts in pelagic sediments. Geochim. Cosmochim. Acia 49, 811-822.

WILSON T. R. S., ThomSON J., HYDes D. J., COLley S., CUlKIN F., and S $\varnothing$ RENSEN J. (1986) Oxidation fronts in pelagic sediments: Diagenetic formation of metal-rich layers. Science 232, 972-975. 